\title{
Molecular and serological surveillance of canine enteric viruses in stray dogs from Vila do Maio, Cape Verde
}

Pedro Castanheira ${ }^{1}$, Ana Duarte ${ }^{1 *}$, Solange Gil ${ }^{1}$, Clara Cartaxeiro ${ }^{1}$, Manuel Malta ${ }^{2}$, Sara Vieira ${ }^{3}$ and Luis Tavares $^{1}$

\begin{abstract}
Background: Infections caused by canine parvovirus, canine distemper virus and canine coronavirus are an important cause of mortality and morbidity in dogs worldwide. Prior to this study, no information was available concerning the incidence and prevalence of these viruses in Cape Verde archipelago.

Results: To provide information regarding the health status of the canine population in Vila do Maio, Maio Island, Cape Verde, 53 rectal swabs were collected from 53 stray dogs during 2010 and 93 rectal swabs and 88 blood samples were collected from 125 stray dogs in 2011. All rectal swabs $(2010 n=53 ; 2011 n=93)$ were analysed for the presence of canine parvovirus, canine distemper virus and canine coronavirus nucleic acids by quantitative PCR methods. Specific antibodies against canine distemper virus and canine parvovirus were also assessed $(2011 \mathrm{n}=88)$. From the 2010 sampling, 43.3\% (23/53) were positive for canine parvovirus DNA, 11.3\% (6/53) for canine distemper virus RNA and 1.9\% (1/53) for canine coronavirus RNA. In 2011, the prevalence values for canine parvovirus and canine coronavirus were quite similar to those from the previous year, respectively $44.1 \%$ (41/93), and 1.1\% (1/93), but canine distemper virus was not detected in any of the samples analysed $(0 \%, 0 / 93)$. Antibodies against canine parvovirus were detected in $71.6 \%$ (63/88) blood samples and the seroprevalence found for canine distemper virus was $51.1 \%(45 / 88)$.
\end{abstract}

Conclusions: This study discloses the data obtained in a molecular and serological epidemiological surveillance carried out in urban populations of stray and domestic animals. Virus transmission and spreading occurs easily in large dog populations leading to high mortality rates particularly in unvaccinated susceptible animals. In addition, these animals can act as disease reservoirs for wild animal populations by occasional contact. Identification of susceptible wildlife of Maio Island is of upmost importance to evaluate the risk of pathogen spill over from domestic to wild animals in Cape Verde and to evaluate the associated threat to the wild susceptible species.

Keywords: Canine coronavirus, Canine distemper virus, Canine parvovirus, Cape verde, Molecular surveillance

\section{Background}

Over the past few years, efforts have been made towards a better understanding of the health status of animal populations, particularly regarding viral infections. Due to their high mutation rate and replication strategies, viruses are responsible for recently recognized emerging diseases, posing a danger not only to domestic and wild animals, but also to humans $[1,2]$.

\footnotetext{
* Correspondence: anaduarte@fmv.utl.pt

${ }^{1}$ Centro de Investigação Interdisciplinar em Sanidade Animal (CIISA),

Faculdade de Medicina Veterinária, Universidade de Lisboa, Lisboa, Portugal

Full list of author information is available at the end of the article
}

The high density of domestic and stray animals in urban areas enables viral dissemination and maintenance in these populations. Consequently, these animals can act as reservoirs of diseases, with the possibility of transmission to wildlife populations through occasional contact.

Canine parvovirus (CPV) was first identified in the late 1970s and was responsible for severe hemorrhagic gastroenteritis and myocarditis in dogs [3]. Parvoviruses are extremely stable in the environment and indirect transmission assumes a critical role in spreading

\section{Biomed Central}

(c) 2014 Castanheira et al.; licensee BioMed Central Ltd. This is an Open Access article distributed under the terms of the Creative Commons Attribution License (http://creativecommons.org/licenses/by/2.0), which permits unrestricted use, distribution, and reproduction in any medium, provided the original work is properly credited. 
and maintenance of the virus in animal populations, especially in wild carnivores, in which contact rates between animals are lower [4]. Shortly after its initial detection, CPV-2 was replaced by two antigenic variants, CPV-2a and CPV-2b and more recently a third variant was described CPV-2c $[5,6]$.

Canine distemper virus (CDV) is the etiological agent of canine distemper, a highly contagious disease, responsible for high mortality rates in dogs worldwide. Sequence analysis of CDV strains originated in different geographical areas from several animal species, showed that the hemagglutinin gene has undergone a genetic drift according to the geographic location $[7,8]$. Phylogenetic analysis based on this gene revealed the existence of at least nine strains in different geographical areas, namely America-1, America-2, Asia-1, Asia-2, Europe-1/ South America 1, European wildlife, Arctic-like, South America 2 and Southern Africa $[9,10]$.

Canine coronavirus ( $\mathrm{CCoV}$ ) causes a mild to moderate enteritis in dogs and its infection is characterized by high morbidity and low mortality. $\mathrm{CCoV}$ is transmitted by faecal-oral route and spreads rapidly through a group of susceptible animals [11]. Stressful environments with large concentrations of animals and poor hygienic conditions, often seen in kennels, favour the development of this disease [12]. Although a higher mortality rate is observed in animals with multiple infections with other pathogens such as CPV-2, canine adenovirus type 1 and CDV, CCoV represents per si a major infectious agent responsible for several epidemics $[13,14]$.

Virological surveys are conducted throughout the world, allowing the detection and analysis of a large variety of viruses in different animal populations. In Cape Verde archipelago to our knowledge, no similar study had been conducted so far. In order to detect the presence of canine viruses on Maio island, samples collected from stray dogs from Vila do Maio were tested for canine parvovirus (CPV), canine distemper virus (CDV) and canine coronavirus $(\mathrm{CCoV})$, to estimate the viral prevalence in this population and investigate the role of these animals in the maintenance and potential spread of common viral pathogens.

\section{Results}

Records were only available for the specimens sampled in 2011. Of the 125 dogs, all them of undetermined or mixed breeds, 65 were females (52\%) and 57 males (46\%). For 3 dogs (2\%) no data was registered regarding gender.

Diaharreic feaces were described for 4 animals (3\%). Only two dogs had been vaccinated, both with Tetradog ${ }^{\circ}$ vaccine and no information regarding vaccination of the rest of the animals was available (NA).
The percentage of positivity for CPV-DNA was very similar in the 2010 and 2011 sampling; 23/53 (43.3\%) and $41 / 93$ (44.1\%, respectively). From the 88 sera sampling collected during 2011, 63 (71.6\%) tested positive for CPV antibodies, with 10 animals included in the first ELISA Unit (EU) class (100-1000 EU), 29 in the second EU class (1000-10000 EU) and 24 in the third EU class (>10000 EU) (Tables 1 and 2).

Antibodies against CPV were detected in $20 \%$ of the animals aged less than 6 months $(2 / 10)$, in $57.1 \%$ in dogs aged between 6 months and 1 year (8/14), in 87.5\% in dogs with 1 to 2 years $(14 / 16)$, in $85.3 \%$ in dogs with 2 to 5 years $(29 / 34)$, in $75 \%$ in dogs with 5 to 7 years $(6 / 8)$ and in $1 / 1$ dog older than 7 years (Figure 1 ). The proportion of seropositive animals was significantly higher in older animals $(\mathrm{p}<0.05)$. No differences were found between the seroprevalence and gender $(p>0.05)$. From the 56 samples that were tested for virology and serology, 46.6\% (26/56) were positive for CPV-DNA and $64.3 \%(36 / 56)$ were seropositive. Out of the 26 dogs that were excreting the virus at the time of collection, 7 were seronegative for CPV specific IgG.

Regarding the 2010 samples tested for CDV-RNA ( $\mathrm{n}=$ 53), 6 animals were positive (11.3\%), of which 2 were also co-infected with CPV. All samples from 2011 were found CDV-RNA negative. As for serology, 45 of the 88 animals sampled during 2011 were seropositive for CDV (51.1\%). Two groups were identified according to the antibody (Ab) titer: 1) low Ab titer (IIF values 1/20-1/40: $\mathrm{n}=43$ (96\%)); and 2) medium Ab titer (IIF values 1/80-1/160: $\mathrm{n}=2(4 \%)$ ).

Antibodies against CDV were detected in $30 \%$ of animals aged less than 6 months (3/10), in $50 \%$ of dogs aged between 6 months and 1 year (7/14), in $56.3 \%$ of dogs with 1 to 2 years (9/16), in $53 \%$ of dogs with 2 to 5 years $(18 / 34)$, in $75 \%$ in dogs with 5 to 7 years $(6 / 8)$ and in $1 / 1$ dog older than 7 years (2011 samples) (Figure 2). Although there was a linear increase of seropositive animals with age, this association was not statistically significant $(\mathrm{p}>0.05)$. The presence of antibodies was independent of gender $(\mathrm{p}>0.05)$.

Only two samples, collected in each year of the survey, tested positive for CCoV-RNA, (2010 (1/53, 1.9\%) and 2011(1/93,1.1\%)).

Table 1 Results of viral nucleic acid investigation in each year (Number of positive samples/total of samples analyzed

\begin{tabular}{lll}
\hline & $\mathbf{2 0 1 0}$ & $\mathbf{2 0 1 1}$ \\
\hline CPV DNA & $23 / 53(43,3 \%)$ & $41 / 93(44,1 \%)$ \\
CDV RNA & $6 / 53(11,3 \%)$ & $0 / 93(0 \%)$ \\
CcoV RNA & $1 / 53(1,9 \%)$ & $1 / 93(1,1 \%)$ \\
\hline
\end{tabular}

The percentage of positivity in each group is indicated between brackets. 
Table 2 Results of serology investigation in 2011 (Number of positive samples/total of samples analyzed)

\begin{tabular}{|c|c|c|c|c|c|c|c|}
\hline \multirow{3}{*}{$\overline{C P V}$} & \multicolumn{7}{|c|}{2011} \\
\hline & \multicolumn{3}{|l|}{ Ab classes } & & \multicolumn{3}{|l|}{ Ab categories } \\
\hline & 100-1000 EU & 1000-10000 EU & $>10000 \mathrm{EU}$ & CDV & Low titer & Medium titer & High titer \\
\hline & & & & & (IIF 1/20-1/40) & (IIF 1/80-1/160) & $(\mathrm{IIF} \geq 1 / 320)$ \\
\hline $\mathrm{n}$ & 10/88 & $29 / 88$ & $24 / 88$ & $n$ & $43 / 88$ & $2 / 88$ & $0 / 88$ \\
\hline Total & & $63 / 88(71,6 \%)$ & & Total & & $45 / 88(51,1 \%)$ & \\
\hline
\end{tabular}

\section{Discussion}

This study describes for the first time, the shedding of three common enteric canine viruses, CPV, CDV and $\mathrm{CCoV}$, in 178 stray dogs from Vila do Maio, Cape Verde and reports data on CPV and CDV seroprevalence.

Samples were collected in two consecutive years, 2010 and 2011. Similar frequency of positive CPV animals was found, namely $43.3 \%$ in 2010 and $44.1 \%$ in 2011, most probably reflecting the high environmental resistance of CPV. Viral transmission and spread of CPV can occur easily, without direct contact between animals. The virus is shed at high titres in faeces and the excretion period may last longer, allowing a higher opportunity for contact between the virus and the new hosts. Although most of the positive dogs did not show signals of diarrhoea, recovered animals may also serve as asymptomatic reservoirs and shed virus periodically, contributing for the persistence and continuous circulation of CPV in the environment, as already reported for cats [15].

Also, the CPV resistance to environmental conditions may explain the high seroprevalence obtained (71.6\%), similar to that reported in studies conducted with nonvaccinated dog populations $[16,17]$. The vast majority of the positive samples presented a high antibody titer $(\mathrm{n}=$ 53) (Table 1 and 2), even though it could not be correlated with hemagglutination inhibition values, the gold standard assay for titration of CPV antibodies, however we did not had the possibility to perform this assay. This observation suggests the persistence of the virus in the environment, which is in accordance with the high percentage of carrier animals found (44.1\%). Within the 56 animals from which both sample types were obtained, CPV-DNA was detected in $46.6 \%$ and seropositivity in $64.3 \%$

Only 7 of the 26 dogs shedding the virus had no circulating antibodies. It is possible that these animals were at an early stage of infection. Primary IgMs were not investigated by the ELISA kit used in this study, which is specific for IgG detection.

The seroprevalence for CPV was significantly higher in older animals $(\mathrm{p}<0.05)$, most probably reflecting a high likelihood of virus exposure over time. Moreover, as younger dogs are more susceptible to the virus, they can succumb to the disease and therefore be removed from the population. Progressive evolution of the CPV-2 led to the emergence of three antigenic variants, $2 \mathrm{a}, 2 \mathrm{~b}$ and 2c, with different properties from the original strain [5]. Monitoring the prevalence of the different CPV in Cape Verde archipelago would be important, not only to assess the distribution of viral variants in this geographic location, but also to understand the evolutionary pattern of the virus in this circunscripted population. In addition, given the high nucleotide substitution rate of $\mathrm{CPV}$, similar to the RNA viruses [18] and the terrain

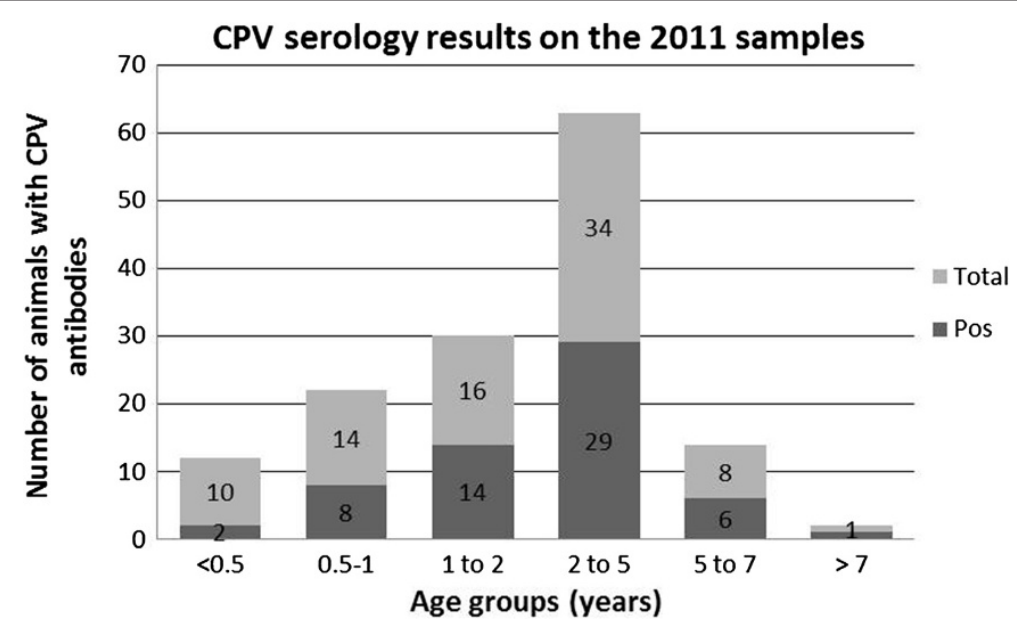

Figure 1 Seropositivity against CPV, accordxing to age class in 2011 sampling. 


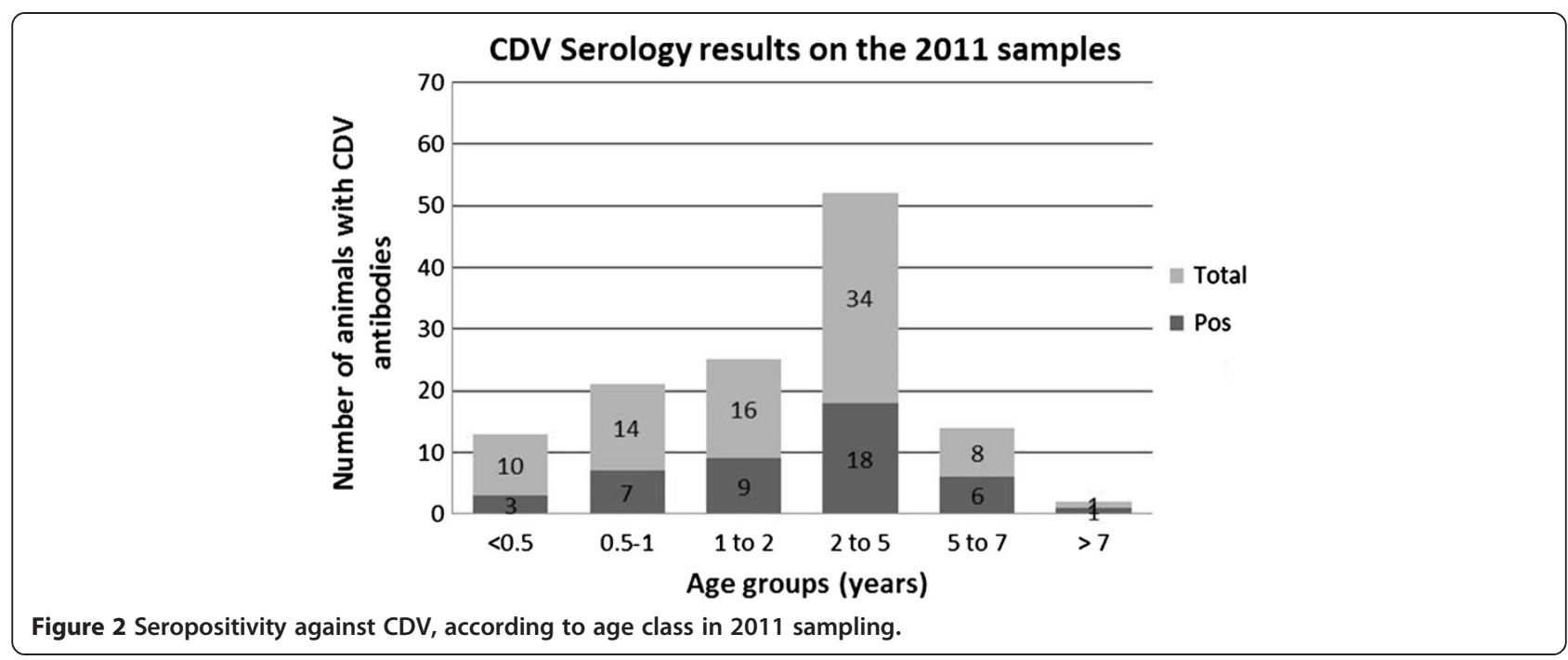

characteristics of Cape Verde as an island its possible transportation through people, goods and infected animals, should be considered.

In 2010 the prevalence of CDV detected by real-time PCR was $11.3 \%$ while in 2011 all the samples were CDVRNA negative. Interestingly, in this year, the seroprevalence obtained for this virus was $51.1 \%$. As these animals were non-vaccinated the explanation for the seropositivity may lie with a previous contact with the virus through ill animals, which could have occurred the previous year.

Several factors may explain the absence of CDV shedding in faeces of dogs sampled in 2011. Taking into account the CDV poor resistance to dry and hot environments, it is possible that the virus did not resist the Cape Verde summer high temperatures, reducing the opportunity for dogs being exposed to the virus $[19,20]$. In addition, the high mortality rates caused by CDV contribute to the low virus spread in canine populations since the animals that succumbed to infection stop shedding. On the other hand, as the animal density of this city is low compared to larger cities, less contact rates between animals affect the virus maintenance and spread [21]. Still, $51.1 \%$ of the animals had anti-CDV antibodies. Comparing the presence of antibodies with the age of the dogs a linear increase in seroprevalence with age was found, which may be related to a possible past CDV outbreak in the population.

Although it is not statistically significant, the higher seroprevalence in older dogs has already been reported [21]. The presence of CDV antibodies was not associated with gender.

All CDV seropositive animals (51.1\%) showed a protective antibody titer, according to Twark and Dodds [22], by establishing a comparison between serum neutralization and IIF assays. Although $96 \%$ of these animals had low antibody titers (Table 1 and 2), Schultz et al. [23] reported that in actively immunized dogs, either naturally or through vaccination, the antibody titer is not very relevant, provided that is detectable. Nevertheless, and despite the good sensitivity and specificity of ELISA, it would be advisable to test the samples using the serum neutralization test to confirm the presence and titer of neutralizing antibodies, to fully assess the immune status of these animal populations.

Relating to the genetic variability of CDV, it would interesting to identify the different CDV genotypes in positive samples, in order to differentiate between vaccine and field strains, and determine which lineages circulate on this island.

Regarding $\mathrm{CCoV}$, we found a low prevalence of $1.9 \%$ in 2010 and $1.1 \%$ in 2011, which is in agreement with similar surveys conducted in areas with similar characteristics of Vila do Maio dog population [24,25]. The low prevalence may indicate a low viral circulation, probably due to the virus instability in normal environmental conditions and also to the reduced number viral particles in faeces. As for CPV, dogs recovered from a CCoV infection may function as asymptomatic reservoirs and shed the virus periodically, resulting in a persistent and continued circulation of $\mathrm{CCoV}$ in the environment. Available data concerning the epidemiological mechanisms of $\mathrm{CCoV}$ suggests that the environment provided by kennels can be fundamental in maintaining this infection in canine populations [25-28].

Seroprevalence against $\mathrm{CCoV}$ was not performed due to the rapid decay of antibodies caused by natural exposure [29]. Moreover the available serological assays are based on the identification of antibodies against $\mathrm{CCoV}$ II, and their efficacy is unknown for the detection of 
Table 3 Sampling distribution per year of collection

\begin{tabular}{lll}
\hline & Year & \\
\cline { 2 - 3 } & $\mathbf{2 0 1 0}$ & $\mathbf{2 0 1 1}$ \\
\hline Rectal Swabs (RS) & 53 & 37 \\
Blood & - & 32 \\
RS + Blood & - & 56 \\
Total & 53 & 125 \\
\hline
\end{tabular}

CCoV-I antibodies [30], questioning the usefulness of these methods.

\section{Conclusion}

The results presented in this study demonstrate that $\mathrm{CPV}, \mathrm{CDV}$ and $\mathrm{CCoV}$ are circulating in the canine population of Vila do Maio, Cape Verde.

The presence of susceptible animals, the high frequency of infections, the prolonged period of virus shedding and environmental persistence of these agents, especially of $\mathrm{CPV}$, contribute to their continuous circulation in this population. Thus, information regarding the spatial distribution of circulating viruses and the risk factors associated with infections will definitely facilitate the planning of control strategies. To our knowledge no vaccination program is undertaken in this region and its implementation could contribute to increase the immunity of this population, reduce viral circulation, and consequently a decrease the population susceptibility to a future disease outbreaks. Additionally, the absence of control measures may increase the risk of pathogen spill over, either for susceptible newcomers' hosts or for resident susceptible new hosts as sympatric carnivores' species.

Due to the wide range of CPV and CDV susceptible hosts, it would be important to identify Maio Island wildlife, to assess the potential risk of infection of these species.

\section{Methods}

\section{Study population and sampling}

Sampling was conducted in Vila do Maio, located on Maio Island, Cape Verde, under a neutering and health surveillance program developed by Veterinarians without Frontiers, Portugal (VSF), in two distinct periods: 2010 with collection of rectal swabs from 53 animals; and
2011, including blood samples $(\mathrm{n}=88)$ and rectal swabs $(\mathrm{n}=93)$ from 125 animals (Table 3). Biological samples were stored under refrigeration until processing.

\section{Sample processing}

Rectal swabs were homogenized in $300 \mu \mathrm{l}$ of PBS. After centrifugation at $10000 \mathrm{xg} / 10 \mathrm{~min}$, the supernatant was collected and stored at $-80^{\circ} \mathrm{C}$. Blood samples were centrifuged at $4000 \mathrm{xg} / 10 \mathrm{~min}$ to separate plasma from blood cells. Plasma was stored at $-20^{\circ} \mathrm{C}$ until processing.

\section{PCR assay procedures}

For viral nucleic acid extraction, $200 \mu \mathrm{l}$ of supernatant from each rectal swab, were processed with the Qiamp Minelute kit ${ }^{\oplus}$ (Qiagen, Germany) according to the manufacturer's instructions, for viral DNA and RNA co-extraction. Although using a commercial kit for co- extraction of viral nucleic acids, from a non-recommended biological matrix may imply a reduced nucleic acid yield, it is sufficient in their experience $[31,32]$.

Detection of viral nucleic acids using real-time PCR (qPCR) and real-time rt-PCR (rt qPCR) CPV DNA was amplified by qPCR using TaqMan ${ }^{\bullet}$ Gene Expression $2 \times$ Master Mix (Applied Biosystems); CDV and CCoV RNA were amplified by rt-qPCR using the TaqMan ${ }^{\circ}$ RNA-to-Ct (TM) 1 step kit in a $20 \mu \mathrm{l}$ reaction with $50 \mathrm{ng}$ of template.

Primers and TaqMan ${ }^{\oplus}$ probes were calculated using the Primer designing tool of NCBI (http://www.ncbi. nlm.nih.gov/tools/primer-blast/). For CPV, primers were based on the nucleotide sequence of the $v p 1$ gene, available through its access number (AN) AB437433.1. CDV primers were chosen within the nucleocapsid gene (AN JN896987.1) [7] and CCoV primers targeted the highly conserved 7b gene (AN JQ404410.1) as already described by [33] (Table 4). A final concentration of $900 \mathrm{nM}$ for the forward primer, $900 \mathrm{nM}$ of reverse primer and $250 \mathrm{nM}$ of each TaqMan ${ }^{\oplus}$ probe was used (Table 4).

The amplification was performed in the StepOne Plus thermocycler (Applied Biosystems) and the cycling conditions comprised an initial denaturation step at $95^{\circ} \mathrm{C}$ for 10 minutes, followed by 40 cycles at $95^{\circ} \mathrm{C}$ for 15 seconds and 1 minute at $60^{\circ} \mathrm{C}$. When the template was RNA the amplification cycle included a reverse transcription step at $48^{\circ} \mathrm{C}$ for 15 minutes.

Table 4 Nucleotide sequences of the primers and probes used in qPCR (CPV) and rt-qPCR (CDV; CCoV) assays

\begin{tabular}{|c|c|c|c|}
\hline Primers/Probe & CPV (vp1 gene AN AB437433.1) & CDV ( $n$ gene AN JN896987.1) & CCoV (7b gene (AN JQ404410.1) \\
\hline Forward $5^{\prime} \rightarrow 3^{\prime}$ & GGGCCTGGGAACAGTCTTGACC (900 nM) & TGGCACTCATTTTGGACATCAA (900 nM) & TGGTCATCGCGCTGTCTACT (900 nM) \\
\hline Reverse $5^{\prime} \rightarrow 3^{\prime}$ & ACCAGAGCGAAGATAAGCAGCG (900 nM) & GCTAACCCAGCTTCCACAATGTA (900 nM) & $\begin{array}{l}\text { AGGGTTGCTTGTACCTCCTATTACA } \\
(900 \mathrm{nM})\end{array}$ \\
\hline $\begin{array}{l}\operatorname{TaqMan}^{\oplus} \text { probe } \\
5^{\prime} \rightarrow 3^{\prime}\end{array}$ & $\begin{array}{l}\text { FAM CGCCGCTGCAAAAGAACACGACGAAGC } \\
\text { TAMRA ( } 250 \mathrm{nM})\end{array}$ & $\begin{array}{l}\text { FAM TCCCCAGGGAACAAGCCTAGAATTGCT } \\
\text { TAMRA ( } 250 \mathrm{nM})\end{array}$ & $\begin{array}{l}\text { FAM TTGTACAGAATGGTAAGCAC } \\
\text { TAMRA ( } 250 \mathrm{nM})\end{array}$ \\
\hline Product & $99 \mathrm{bp}$ & $100 \mathrm{bp}$ & $66 \mathrm{bp}$ \\
\hline
\end{tabular}


For CPV tenfold dilutions of CPV-2-780 916 Cornell strain (Tetradog, Merial) were used as positive control. Regarding CDV, a 287 bp fragment, including the targeted region was amplified from CDV RNA (Caniffa ${ }^{\bullet}$, Merial) [7] and cloned in $\mathrm{pGEM}^{\odot}$ Teasy vector (Promega) according to the manufactures instructions. The CDV recombinant plasmid was used as positive control. A similar approach was used for CCoV as already described [34].

The assay specificity was confirmed by direct sequencing of the CPV amplicon. For CDV and CCoV sequencing was performed after plasmid cloning. No cross reactivity was detected between $\mathrm{CDV} / \mathrm{CCoV} / \mathrm{CPV}$. The sensitivity of the rt-qPCR/qPCR for all three agents surpassed the detection of 10 target copies/ $\mu \mathrm{l}$, assessed by conversion of the positive control mass $(\mathrm{g} / \mu \mathrm{l})$ in molecules/ $\mu \mathrm{l}$, based on the following formula: number of copies $($ molecules $/ \mu \mathrm{l})=[$ mass $(\mathrm{g} / \mu \mathrm{l}) /($ number of base pairs $\mathrm{x}$ bp (660)] x Avogadro's number (6,022 x 10 $\left.{ }^{23}\right)$.

\section{Antibody detection}

Antibody (Ab) detection was only performed for 2011 serum samples for CPV and CDV using an indirect ELISA kit (Ingezim Canine Parvo 15.CPV.K1 ${ }^{\circ}$ and Ingezim Moquillo 1.5.CDG.K.1 ${ }^{\circ}$-Ingenasa), for specific IgG detection, according to the manufactures instructions.

This method allowed the quantification of the $A b$ titer for CPV, using a formula provided by the kit, although it did not specify the correspondence with the hemagglutination inhibition assay for quantification of anti-CPV antibodies. The values were organized in three classes: 1) 100-1000 ELISA Units (EU); 2) 1000$10000 \mathrm{EU}$ and 3) > $10000 \mathrm{EU}$.

For CDV the OD values had correspondence with the indirect immunofluorescence (IIF) method, and the values were divided into three categories: 1 ) low titer (IIF values: 1/20-1/40), 2) medium titer (IIF values: $1 / 80-1 / 160$ ) and 3) high titer (IIF values: $\geq 1 / 320$ ).

\section{Statistical analysis}

A possible association between serological findings and the age and gender of the animals was determined by chisquare statistical test $\left(X^{2}\right)$ with IBM SPSS Statistics 19.0 software. A P value $<0.05$ was considered significant.

\section{Competing interest}

The authors declare that they have no competing interests.

\begin{abstract}
Authors' contributions
$P C, A D$ and $L T$ were responsible for the conception and the study design and actively participated in the analysis and data interpretation. PC and AD were also involved in the drafting and revision of the article. SG and CC were involved in the data analysis. MM and SV were responsible for the organization of the field work and sample collection.
\end{abstract}

\section{Acknowledgements}

This work was sponsored by CIISA/FCT as part of an Integrated Master degree in Veterinary Medicine. We wish to acknowledge Cristina Pereira,
Raquel Vilaça, Conceição Almeida, Margarida Simões, Inês Cunha, Catarina Vieira DVMs of the Veterinarians without Frontiers, Portugal, who helped providing the biological sampling. We also recognize Margarida Duarte $(\mathrm{PhD})$ for the revision of the manuscript and Fátima Cordeiro both from Instituto Nacional de Investigação Agrária e Veterinária, I.P., Laboratório de Virologia and Professora Doutora Isabel Neto from FMV/UL. Solange Gil is a Research Assistant under Programa Ciência 2007.

\section{Author details}

${ }^{1}$ Centro de Investigação Interdisciplinar em Sanidade Animal (CIISA), Faculdade de Medicina Veterinária, Universidade de Lisboa, Lisboa, Portugal. ${ }^{2}$ Veterinários Sem Fronteiras de Portugal, Faculdade de Medicina Veterinária, Universidade de Lisboa, Lisboa, Portugal. ${ }^{3}$ Delegação do Ministério do Desenvolvimento Rural, Ilha do Maio, Cape Verde.

Received: 18 April 2013 Accepted: 16 April 2014

Published: 23 April 2014

\section{References}

1. Cleaveland S: Viral threats and vaccination: disease management of endangered species. Anim Conserv 2009, 12:187-189.

2. Parrish CR, Holmes EC, Morens DM, Park EC, Burke DS, Calisher CH, Laughlin $C A$, Saif $L J$, Daszak P: Cross-species virus transmission and the emergence of new epidemic diseases. Microbiol Mol Biol R 2008, 72:457-470.

3. Appel MJG, Scott WF, Carmichael LE: Isolation and immunization studies of canine parvo-like virus from dogs with haemorrhagic enteritis. Vet Rec 1979, 105:156-159.

4. Hoelzer K, Parrish CR: The emergence of parvoviruses of carnivores. Vet Res 2010, 41:39.

5. Decaro N, Elia G, Martella V, Campolo M, Desario C, Camero M, Cirone F, Lorusso E, Lucente MS, Narcisi D, Scalia P, Buonavoglia C: Characterisation of the canine parvovirus type 2 variants using minor groove binder probe technology. J Virol Methods 2006, 133:92-99.

6. Nakamura M, Tohya Y, Miyazawa T, Mochizuki M, Phung HT, Nguyen NH, Huynh LM, Nguyen LT, Nguyen PN, Nguyen PV, Nguyen NP, Akashi H: A novel antigenic variant of Canine parvovirus from a Vietnamese dog. Arch Virol 2004, 149:2261-2269

7. Frisk AL, Konig M, Moritz A, Baumgartner W: Detection of canine distemper virus nucleoprotein RNA by reverse transcription-PCR using serum, whole blood, and cerebrospinal fluid from dogs with distemper. J Clin Microbiol 1999, 37:3634-3643.

8. Martella V, Elia G, Lucente MS, Decaro N, Lorusso E, Banyai K, BlixenkroneMoller M, Lan NT, Yamaguchi R, Cirone F, Carmichael LE, Buonavoglia C: Genotyping canine distemper virus (CDV) by a hemi-nested multiplex PCR provides a rapid approach for investigation of CDV outbreaks. Vet Microbiol 2007, 122:32-42

9. Panzera Y, Calderón MG, Sarute N, Guasco S, Cardeillac A, Bonilla B, Hernández M, Francia L, Bedó G, La Torre J, Pérez R: Evidence of two co-circulating genetic lineages of canine distemper virus in South America. Virus Res 2012, 163:401-404.

10. Woma TY, Van Vuuren M, Bosman A-M, Quan M, Oosthuizen M: Phylogenetic analysis of the haemagglutinin gene of current wild-type canine distemper viruses from South Africa: Lineage Africa. Vet Microbiol 2010, 143:126-132.

11. McCaw DL, Hoskins JD: Canine Viral Enteritis. In Infectious Diseases of the Dog and Cat Revised Reprint. 3rd edition. St Louis, Missouri: Saunders; 2006:63-73).

12. Pratelli A: Canine coronavirus inactivation with physical and chemical agents. Vet J 2008, 177:71-79.

13. Decaro N, Buonavoglia C: An update on canine coronaviruses: Viral evolution and pathobiology. Vet Microbiol 2008, 132:221-234.

14. Pratelli A: Genetic evolution of canine coronavirus and recent advances in prophylaxis. Vet Res 2006, 37:191-200.

15. Clegg SR, Coyne KP, Dawson S, Spibey N, Gaskell RM, Radford AD: Canine parvovirus in asymptomatic feline carriers. Vet Microbiol 2012, 157:78-85.

16. Carman PS, Povey RC: The seroprevalence of canine parvovirus- 2 in a selected sample of the canine population in ontario. Can Vet J 1984, 25:259-262

17. Yang D, Yoon S, Byun J, Lee $K$, Oh Y, Song J: Serological survey for canine parvovirus type 2a (CPV-2a) in the stray dogs in South Korea. J Bacteriol Virol 2010, 40:77-81. 
18. Shackelton LA, Parrish CR, Truyen U, Holmes EC: High rate of viral evolution associated with the emergence of carnivore parvovirus. Proc Natl Acad Sci U S A 2005, 102:379-384.

19. Chabchoub A, Hajjem S, Calleja C, Chalvet-Monfray K, Landolsi F, Incorvia G, El Goulli A, Artois M: Parvovirose et maladie de Carré chez le chien: enquête séro-épidémiologique dans le sud tunisien. Rev Med Vet-Toulouse 2008, 159:224-229.

20. Lechner ES, Crawford PC, Levy JK, Edinboro CH, Dubovi EJ, Caligiuri R: Prevalence of protective antibody titers for canine distemper virus and canine parvovirus in dogs entering a Florida animal shelter. JAMA-J Am Med Assoc 2010, 236:1317-1321.

21. Acosta-Jamett G, Chalmers WSK, Cunningham AA, Cleaveland S, Handel IG, Bronsvoort BM: Urban domestic dog populations as a source of canine distemper virus for wild carnivores in the Coquimbo region of Chile. Vet Microbiol 2011, 152:247-257.

22. Twark L, Dodds WJ: Clinical use of serum parvovirus and distemper virus antibody titers for determining revaccination strategies in healthy dogs. JAMA-J Am Med Assoc 2000, 217:1021-1024.

23. Schultz RD, Thiel B, Mukhtar E, Sharp P, Larson L: Age and Long-term Protective Immunity in Dogs and Cats. Jf Comp Pathol 2010, 142(1):S102-S108.

24. McElligott S, Collins PJ, Sleator RD, Martella V, Decaro N, Buonavoglia C, $\mathrm{O}$ 'Shea $\mathrm{H}$ : Detection and genetic characterization of canine parvoviruses and coronaviruses in southern Ireland. Arch Virol 2011, 156:495-503.

25. Stavisky J, Pinchbeck G, Gaskell RM, Dawson S, German AJ, Radford AD: Cross sectional and longitudinal surveys of canine enteric coronavirus infection in kennelled dogs: A molecular marker for biosecurity. Infect Genet Evol 2012, 12:1419-1426.

26. Tennant BJ, Gaskell RM, Jones RC, Gaskell CJ: Studies on the epizootiology of canine coronavirus. Vet Rec 1993, 132:7-11.

27. Naylor MJ, Harrison GA, Monckton RP, McOrist S, Lehrbach PR, Deane EM: Identification of canine coronavirus strains from feces by $S$ gene nested PCR and molecular characterization of a new Australian isolate. J Clin Microbiol 2001, 39:1036-1041.

28. Ntafis V, Mari V, Danika S, Fragkiadaki E, Buonavoglia C: An Outbreak of Canine Coronavirus in Puppies in a Greek Kennel. J Vet Diagn Invest 2010, 22:320-323.

29. Zarnke RL, Evermann J, Ver Hoef JM, McNay ME, Boertje RD, Gardner CL, Adams LG, Dale BW, Burch J: Serologic survey for canine coronavirus in wolves from Alaska. Jf Wildlive Dis 2001, 37:740-745

30. Stavisky J, Pinchbeck GL, German AJ, Dawson S, Gaskell RM, Ryvar R, Radford AD: Prevalence of canine enteric coronavirus in a cross-sectional survey of dogs presenting at veterinary practices. Vet Microbiol 2010, 140:18-24.

31. Duarte A, Veiga I, Tavares L: Genetic diversity and phylogenetic analysis of feline coronavirus sequences from portugal. Vet Microbiol 2009, 138:163-168.

32. Duarte A, Fernandes M, Santos N, Tavares L: Virological survey in free-ranging wildcats (Felis silvestris) and feral domestic cats in Portugal. Vet Microbiol 2012, 58:400-404.

33. Gil S, Leal RO, Duarte A, McGahie D, Sepúlveda N, Siborro I, Cravo J, Cartaxeiro C Tavares $L M$ : Relevance of feline interferon omega for clinical improvement and reduction of concurrent viral excretion in retrovirus infected cats from a rescue shelter. Res Vet Sci 2013, 94:753-763.

34. Duarte A, Tavares L: Utilização de um ensaio de RT-PCR-nested PCR para avaliação da infecção do coronavírus felino. Rev Port Ciências Vet 2007, 102:65-70.

\section{Submit your next manuscript to BioMed Central and take full advantage of:}

- Convenient online submission

- Thorough peer review

- No space constraints or color figure charges

- Immediate publication on acceptance

- Inclusion in PubMed, CAS, Scopus and Google Scholar

- Research which is freely available for redistribution 